\title{
Erratum behorend bij: Vitale pulpabehandeling
}

Erratum behorend bij:

Hoofdstuk 10 in: Prof. dr. S.K. Thoden van Velzen en Prof. dr. P.R. Wesselink, Endodontologie

DOI 10.1007/978-90-313-7377-2_10

Rectificatie van het figuurbijschrift behorende bij figuur 10.2 op pagina 165.

a Bite-wingopname, diepe cariës mesiaal van element 26.

b Behandeling uitgevoerd bijna 8 maanden na de bitewingopname : schone glazuur/ dentinegrens, centraal blijft scharlaken rood gekleurd dentine achter.

c Onderlaag kunststofgemodificeerd glasionomeercement.

d Solo-opname element 26 na 3 jaar.

(Foto’s ter beschikking gesteld door R. Gruythuysen). 